\title{
Bone morphogenetic proteins and the polycystic ovary syndrome
}

\author{
E Leonie AF van Houten ${ }^{1}$, Joop SE Laven², Yvonne V Louwers², Anke McLuskey ${ }^{1}$, Axel PN Themmen \\ and Jenny A Visser ${ }^{1 *}$
}

\begin{abstract}
Background: Polycystic Ovary Syndrome (PCOS) is defined by two out of the following three criteria being met: oligo- or anovulation, hyperandrogenism, and polycystic ovaries. Affected women are often obese and insulin resistant. Although the etiology is still unknown, members of the Transforming Growth Factor $\beta$ (TGF $\beta$ ) family, including Bone Morphogenetic Proteins (BMPs) and anti-Müllerian hormone (AMH), have been implicated to play a role. In this pilot study we aimed to measure serum BMP levels in PCOS patients.

Methods: Twenty patients, fulfilling the definition of PCOS according to the Rotterdam Criteria, were randomly selected. Serum BMP2, $-4,-6$ and -7 levels were measured using commercially available BMP2, BMP4, BMP6 and BMP7 immunoassays.

Results: Serum BMP2, serum BMP4 and serum BMP6 levels were undetectable. Three patients had detectable serum BMP7 levels, albeit at the lower limit of the standard curve.

Conclusions: BMP levels were undetectable in almost all patients. This suggests that with the current sensitivity of the BMP assays, measurement of serum BMP levels is not suitable as a diagnostic tool for PCOS.
\end{abstract}

Keywords: BMPs, PCOS, Marker, Assay

\section{Introduction}

Polycystic Ovary Syndrome (PCOS) is one of the most common endocrine disorders in premenopausal women [1]. The diagnosis is based on two of the following three criteria being met: hyperandrogenism, oligo- or anovulation, and polycystic ovaries [2]. PCOS is the most frequent cause of infertility in women in their reproductive years, affecting $6-8 \%$ of women in the general population worldwide. Besides the reproductive phenotype, women with PCOS often display a metabolic phenotype: $38-88 \%$ of women with PCOS are obese with a characteristic abdominal distribution of fat and up to $70 \%$ are insulin resistant and some are found to have type II Diabetes Mellitus [3,4]. Although the etiology is unknown, it is generally agreed that elevated androgens are the main culprit of the syndrome [5]. The increased ovarian androgen production may result from the increased GnRH pulsatility, which leads to increased LH secretion in

\footnotetext{
* Correspondence: j.visser@erasmusmc.nl

'Department of Internal Medicine, Room Ee532, Erasmus MC, P.O Box 2040, Rotterdam, CA 3000, The Netherlands

Full list of author information is available at the end of the article
}

favor of FSH [6]. Combined with the advanced LH responsiveness of small growing follicles, this causes increased androgen production, which is further enhanced by the elevated insulin levels. This abnormal endocrine environment has been suggested to suppress FSH action and causing follicular arrest [7]. In addition, intrinsic alterations in folliculogenesis have been proposed to contribute to the failure in dominant follicle selection in PCOS [7]. Ovarian growth factors, such as members of the transforming growth factor $\beta$ (TGF $\beta$ ) family, play important roles in follicle recruitment, follicle selection, and FSH responsiveness. Studies performed predominantly in rodents showed that the various Bone Morphogenetic Proteins (BMPs) are expressed in a cell-specific manner in the ovary, and display spatial and temporal changes in expression depending on the stage of follicular development [8-10]. BMP15 is specifically expressed by oocytes [11], also in ovine, bovine and human, whereas BMP6 has an oocyte/ granulosa cell expression pattern in various species. BMP2 is expressed by granulosa cells in rodents and
C Biomed Central

(c) 2013 van Houten et al.; licensee BioMed Central Ltd. This is an Open Access article distributed under the terms of the Creative Commons Attribution License (http://creativecommons.org/licenses/by/2.0), which permits unrestricted use, distribution, and reproduction in any medium, provided the original work is properly cited. 
bovine, while BMP4 and BMP7 are theca cells derived growth factors with mRNA expression detectable from the small preantral stage onwards in rats $[8,12]$. However, in mouse, human and bovine ovaries also granulosa cell expression of BMP4 mRNA has been reported [13-15]. AntiMüllerian hormone (AMH) is specifically expressed by the granulosa cells of small growing follicles in various species including human [16]. BMPs and AMH differently regulate $\mathrm{FSH}$ responsiveness and FSH-induced steroidogenesis, hence it has been suggested that these factors may contribute to the pathogenesis of PCOS.

Several studies have shown that serum AMH levels are elevated in women with PCOS. These elevated levels reflect the increased antral follicle count (AFC) in PCOS. In addition, AMH production per granulosa cell appears to be increased [17-19]. Whether serum BMP levels are altered in women with PCOS is unknown.

Given the role of BMPs in FSH-responsiveness and $\mathrm{FSH}$-induced steroidogenesis, we investigated whether serum BMP levels could be used as a diagnostic tool for PCOS.

\section{Materials and methods Patients}

Twenty normogonadotrophic normoestrogenic dysovulatory patients, fulfilling the definition of PCOS according to the Rotterdam Criteria [2], were selected from the Rotterdam PCOS cohort, which comprises of PCOS patients attending our fertility clinic between 1997 and 2011. Standardized initial screening (clinical investigation, transvaginal ultrasound, and fasting blood withdrawal) was performed on a random cycle day between 0900 and 1100 $\mathrm{h}$, irrespective of the interval between blood sampling and the preceding bleeding, as previously described [20]. Biochemically hyperandrogenemia was defined as an elevated $(>4.5)$ free androgen index (testosterone $\times 100 /$ SHBG) and clinical hyperandrogenemia was defined as a Ferriman Gallway score $>8$. Polycystic ovaries were defined as 12 or more follicles (measuring 2-9 $\mathrm{mm}$ ) per ovary, and/or an ovarian volume above $10 \mathrm{ml}$ [21]. Endocrine screening included assessment of serum AMH, testosterone and SHBG levels and were determined previously [22,23]. Briefly, blood samples were stored at $-20 \mathrm{C}$ until further assessments were made. Serum hormone levels were assessed at the time patients were originally seen. Serum SHBG was measured by luminescence-based immunometric assays (Immulite 2000, Diagnostic Products Corp., Los Angeles, CA). Serum testosterone was measured using a RIA (Diagnostic Products Corp.). AMH levels were measured collectively in samples stored, using an in-house AMH ELISA assay (commercially available through Beckman Coulter, Woerden, The Netherlands). Approval by the local medical ethics committee was obtained and all participants have given informed consent.

\section{BMP measurements}

Serum BMP2, -4 and -7 levels were measured using a Quantikine BMP2, BMP4 and BMP7 Immunoassay (R\&D Systems, Minneapolis, MN, USA). Serum BMP6 levels were measured using a human BMP6 DuoSet ELISA Development kit (also R\&D Systems). All samples were measured in single measurements according to the manufacturer's instructions. For BMP2 the detection limit of the assay was between $62.5 \mathrm{pg} / \mathrm{mL}$ and $4000 \mathrm{pg} / \mathrm{mL}$. For BMP4 and -7 the detection limits of the assay were between $31.2 \mathrm{pg} / \mathrm{mL}$ and $2000 \mathrm{pg} / \mathrm{mL}$. For BMP6 the detection limit of the assay was between $78.13 \mathrm{pg} / \mathrm{mL}$ and 1000 $\mathrm{pg} / \mathrm{mL}$. Controls with low, medium and high concentrations for BMP2 (207-558 pg/mL, 759-1509 pg/mL, 1670-3061 pg/mL), BMP4 (89-140 pg/mL, 512-780 $\mathrm{pg} / \mathrm{mL}, 958-1468 \mathrm{pg} / \mathrm{mL})$ and BMP7 (180-248 pg/mL, 502-698 pg/mL, 1010-1442 pg/mL) were provided by R\&D Systems. For BMP6 controls were not available. All samples where measured in one plate per assay.

\section{Results}

PCOS patient characteristics are given in Table 1. Serum BMP7 was detectable in only three of the 20 PCOS patients (Table 1), albeit at very low levels. Serum BMP2, -4 and -6 were undetectable in all PCOS patients (Table 1). Extending the standard curve with an extra dilution step, allowed the detection of serum BMP4 in only one patient, whereas BMP2 and -6 remained undetectable. In contrast, serum $\mathrm{AMH}$ levels were easily detectable at an average concentration of $20.9 \mathrm{ng} / \mathrm{mL}$. For four patients AMH levels were unknown, because data and serum of these patients were collected before AMH measurements were routinely determined in the clinic.

\section{Discussion}

In this pilot study, $\mathrm{BMP} 2,-4$ and -6 were undetectable in all PCOS patients. BMP7 was detectable in only three patients, but with levels close to the lower limit of the standard curve. The addition of an extra lowest point to the standard curve did not improve the measurement of BMPs. The patients with discernible serum BMP7 values did not show a consistent pattern with respect to FAI, BMI or AFC. Since the BMPs studied were undetectable in nearly all of the twenty PCOS patients, and therefore could not be used to further distinguish the heterogeneous PCOS population, we did not attempt to analyze a larger number of PCOS patients nor a cohort of normoovulatory women as controls.

In a recent study by Son et al. [24], serum BMP4 levels were measured in male and female subjects and shown to be associated with adiposity, insulin resistance and the metabolic syndrome. BMP4 levels ranged between $0.63 \pm 0.41 \mathrm{pg} / \mathrm{mL}$ and $9.91 \pm 4.48 \mathrm{pg} / \mathrm{mL}$ and were determined with the same assay as in our study. Since the 
Table 1 Clinical characteristics and BMP levels in PCOS women

\begin{tabular}{|c|c|c|c|c|c|c|c|c|c|}
\hline Patient & Age (years) & FAI & BMI $\left(\mathrm{kg} / \mathrm{m}^{2}\right)$ & AFC & AMH (ng/ml) & BMP2 $(\mathrm{pg} / \mathrm{mL})$ & BMP4 (pg/mL) & BMP6 (pg/mL) & BMP7 (pg/mL) \\
\hline 1 & 28 & 1.63 & 21.6 & 42 & 13.2 & - & - & - & - \\
\hline 2 & 28 & 0.92 & 22 & 55 & 28.7 & - & - & - & - \\
\hline 3 & 30 & 1.68 & 20 & 47 & 15.8 & - & - & - & - \\
\hline 4 & 20 & 0.62 & 22.2 & 50 & 20 & - & - & - & - \\
\hline 5 & 30 & 1.03 & 19.6 & 59 & 31.9 & - & - & - & 57.60 \\
\hline 6 & 30 & 7.93 & 24.6 & 40 & 30.9 & - & - & - & - \\
\hline 7 & 23 & 5.53 & 19.4 & 73 & 28.5 & - & - & - & - \\
\hline 8 & 22 & 5.70 & 21.1 & 54 & n.d. & - & - & - & - \\
\hline 9 & 20 & 5.50 & 24.7 & 62 & n.d. & - & - & - & 43.88 \\
\hline 10 & 25 & 13.27 & 24.2 & 48 & 26.6 & - & - & - & - \\
\hline 11 & 25 & 1.50 & 30.4 & 32 & 6.5 & - & - & - & - \\
\hline 12 & 31 & 1.75 & 44.1 & 77 & 23.5 & - & - & - & - \\
\hline 13 & 31 & 1.42 & 30.1 & 41 & 8.8 & - & - & - & - \\
\hline 14 & 24 & 1.21 & 31.8 & 44 & 13.6 & - & - & - & - \\
\hline 15 & 26 & 13.50 & 30.1 & 160 & n.d. & - & - & - & - \\
\hline 16 & 25 & 15.13 & 32.3 & 153 & 37 & - & - & - & 42.38 \\
\hline 17 & 27 & 19.20 & 32.7 & 110 & n.d. & - & - & - & - \\
\hline 18 & 27 & 9.20 & 32.0 & 103 & 17.8 & - & - & - & - \\
\hline 19 & 28 & 9.50 & 34.3 & 101 & n.d. & - & - & - & - \\
\hline 20 & 23 & 26.57 & 43.2 & 91 & 26.6 & - & - & - & - \\
\hline
\end{tabular}

FAl: Free Androgen Index; BMI: Body Mass Index; AFC: Antral Follicle count. n.d.: not determined.

- : below detection limit of the assay.

lowest point of the standard curve of the BMP4 assay is $31.2 \mathrm{pg} / \mathrm{mL}$, these values are well below the standard curve, and therefore it is unclear whether the results of Son et al. have any practical implications. Associations of BMP4 values that far below the detection range are weak at best.

Conflicting results have also been reported for BMP2 and BMP7. Using the same assay, one study showed that serum BMP2 levels were undetectable in patients with femoral fractures [25], whereas in another study, serum BMP2 and -7 levels $[10,26,27]$ could be detected in patients with ankylosing spondylitis, arthritis and healthy subjects [28]. Also, in the latter study BMP levels were near or below the detection range of the assay. In agreement, other studies have also shown that serum BMP7 levels are often below or close to the standard curve of the assay $[29,30]$.

All women used in this study had polycystic ovaries and in accordance with these results increased AMH levels. An explanation for the undetectable serum BMP levels in this study could be that BMPs are not secreted by the human ovary, although it has been reported that BMP2, $-4,-6$ and 7 are expressed by the human ovary [9]. This explanation may not be likely since this would be in contrast to other ovarian expressed TGF $\beta$ family members that are secreted, such as $\mathrm{AMH}$, Inhibin $\mathrm{B}$ and Activin A [18,31]. Alternatively, BMP immunoreactivity may not have been preserved. Prolonged storage and repeated freeze/thawing of the samples did not affect the immunoreactivity of $\mathrm{AMH}$, a family member of BMPs, but an effect on BMP immunoreactivity cannot be ruled out. However, based on the studies mentioned above and our own study, we prefer to suggest an alternative reason, namely that the current available BMP assays are not sensitive enough to detect BMP ligands in the circulation of human subjects. Therefore, more sensitive assays are necessary to determine whether serum BMP levels could be used as an additional diagnostic tool in PCOS and other metabolic diseases.

\section{Competing interests}

The authors declare that they have no competing interests.

\section{Authors' contributions}

ELAFVH performed the experiments, analyzed and interpreted data, and drafted the manuscript. JSEL and $Y V L$ acquired patient data and samples, and contributed to the writing of the manuscript. AM performed the experiments. APNT conceived and designed the study, and contributed to the writing of the manuscript. JAV conceived and designed the study, supervised the work and co-wrote the manuscript. All authors have read and approved the final manuscript. 


\section{Author details}

${ }^{1}$ Department of Internal Medicine, Room Ee532, Erasmus MC, P.O Box 2040, Rotterdam, CA 3000, The Netherlands. 'Division of Reproductive Medicine, Department of Gynecology and Obstetrics, Erasmus MC, Rotterdam, The Netherlands.

Received: 8 January 2013 Accepted: 21 April 2013

Published: 30 April 2013

\section{References}

1. Franks S: Polycystic ovary syndrome. N Engl J Med 1995, 333:853-861

2. The Rotterdam ESHRE/ASRM-Sponsored PCOS Consensus Workshop Group: Revised 2003 consensus on diagnostic criteria and long-term health risks related to polycystic ovary syndrome (PCOS). Hum Reprod 2004, 19:41-47.

3. Escobar-Morreale HF, San Millan JL: Abdominal adiposity and the polycystic ovary syndrome. TEM 2007, 18:266-272.

4. Franks S, Gharani N, Gilling-Smith C: Polycystic ovary syndrome: evidence for a primary disorder of ovarian steroidogenesis. J Steroid Biochem Mol Biol 1999, 69:269-272.

5. Homburg R: Androgen circle of polycystic ovary syndrome. Hum Reprod 2009, 24:1548-1555.

6. Blank SK, McCartney CR, Marshall JC: The origins and sequelae of abnormal neuroendocrine function in polycystic ovary syndrome. Hum Reprod Update 2006, 12:351-361.

7. Franks S, Mason H, Willis D: Follicular dynamics in the polycystic ovary syndrome. Mol Cell Endocrinol 2000, 163:49-52.

8. Erickson GF, Shimasaki S: The spatiotemporal expression pattern of the bone morphogenetic protein family in rat ovary cell types during the estrous cycle. Reprod Biol Endocrinol 2003, 1:9.

9. Knight PG, Glister C: TGF-beta superfamily members and ovarian follicle development. Reproduction (Cambridge, England) 2006, 132:191-206.

10. Shimasaki S, Moore RK, Otsuka F, Erickson GF: The bone morphogenetic protein system in mammalian reproduction. Endocr Rev 2004, 25:72-101.

11. Elvin JA, Yan C, Matzuk MM: Oocyte-expressed TGF-beta superfamily members in female fertility. Mol Cell Endocrinol 2000, 159:1-5.

12. Baarends WM, Uilenbroek JT, Kramer P, Hoogerbrugge JW, van Leeuwen EC, Themmen AP, Grootegoed JA: Anti-mullerian hormone and anti-mullerian hormone type II receptor messenger ribonucleic acid expression in rat ovaries during postnatal development, the estrous cycle, and gonadotropin-induced follicle growth. Endocrinology 1995, 136:4951-4962.

13. Fatehi AN, van den Hurk R, Colenbrander B, Daemen AJ, van Tol HT, Monteiro RM, Roelen BA, Bevers MM: Expression of bone morphogenetic protein2 (BMP2), BMP4 and BMP receptors in the bovine ovary but absence of effects of BMP2 and BMP4 during IVM on bovine oocyte nuclear maturation and subsequent embryo development. Theriogenology 2005, 63:872-889.

14. Khalaf M, Morera J, Bourret A, Reznik Y, Denoual C, Herlicoviez M, Mittre H, Benhaim A: BMP system expression in GCs from polycystic ovary syndrome women and the in vitro effects of BMP4, BMP6, and BMP7 on GC steroidogenesis. Eur J Endocrinol 2013, 168:437-444.

15. von Schalburg KR, McCarthy SP, Rise ML, Hutson JC, Davidson WS, Koop BF: Expression of morphogenic genes in mature ovarian and testicular tissues: potential stem-cell niche markers and patterning factors. $\mathrm{Mol}$ Reprod Dev 2006, 73:142-152.

16. Visser JA, de Jong FH, Laven JS, Themmen AP: Anti-Mullerian hormone: a new marker for ovarian function. Reproduction (Cambridge, England) 2006, 131:1-9.

17. Cook CL, Siow Y, Brenner AG, Fallat ME: Relationship between serum mullerian-inhibiting substance and other reproductive hormones in untreated women with polycystic ovary syndrome and normal women. Fertil Steril 2002, 77:141-146.

18. Laven JS, Mulders AG, Visser JA, Themmen AP, De Jong FH, Fauser BC: AntiMullerian hormone serum concentrations in normoovulatory and anovulatory women of reproductive age. J Clin Endocrinol Metab 2004, 89:318-323.

19. Pellatt L, Hanna L, Brincat M, Galea R, Brain H, Whitehead S, Mason H: Granulosa cell production of anti-Mullerian hormone is increased in polycystic ovaries. J Clin Endocrinol Metab 2007, 92:240-245.

20. Imani B, Eijkemans MJ, te Velde ER, Habbema JD, Fauser BC: Predictors of patients remaining anovulatory during clomiphene citrate induction of ovulation in normogonadotropic oligoamenorrheic infertility. J Clin Endocrinol Metab 1998, 83:2361-2365.
21. van Santbrink EJ, Hop WC, Fauser BC: Classification of normogonadotropic infertility: polycystic ovaries diagnosed by ultrasound versus endocrine characteristics of polycystic ovary syndrome. Fertil Steril 1997, 67:452-458.

22. Kevenaar ME, Laven JS, Fong SL, Uitterlinden AG, de Jong FH, Themmen AP, Visser JA: A functional anti-mullerian hormone gene polymorphism is associated with follicle number and androgen levels in polycystic ovary syndrome patients. J Clin Endocrinol Metab 2008, 93:1310-1316.

23. Lie Fong S, Schipper I, de Jong FH, Themmen AP, Visser JA, Laven JS: Serum anti-Mullerian hormone and inhibin $B$ concentrations are not useful predictors of ovarian response during ovulation induction treatment with recombinant follicle-stimulating hormone in women with polycystic ovary syndrome. Fertil Steril 2011, 96:459-463.

24. Son JW, Kim MK, Park YM, Baek KH, Yoo SJ, Song KH, Son HS, Yoon KH, Lee WC, Cha BY, et al: Association of serum bone morphogenetic protein 4 levels with obesity and metabolic syndrome in non-diabetic individuals. Endocr J 2011, 58:39-46.

25. Giannoudis PV, Pountos I, Morley J, Perry S, Tarkin HI, Pape HC: Growth factor release following femoral nailing. Bone 2008, 42:751-757.

26. Gilchrist RB, Ritter $\amalg$, Armstrong DT: Oocyte-somatic cell interactions during follicle development in mammals. Anim Reprod Sci 2004, 82-83:431-446.

27. McNatty KP, Smith P, Moore LG, Reader K, Lun S, Hanrahan JP, Groome NP, Laitinen M, Ritvos $\mathrm{O}$, Juengel JL: Oocyte-expressed genes affecting ovulation rate. Mol Cell Endocrinol 2005, 234:57-66.

28. Park MC, Park YB, Lee SK: Relationship of bone morphogenetic proteins to disease activity and radiographic damage in patients with ankylosing spondylitis. Scand J Rheumatol 2008, 37:200-204.

29. Bozkaya YT, Aydin HH, Celik HA, Kayikcioglu M, Payzin S, Kultursay H, Aydin M, Yesil M, Can LH, Hasdemir C: Increased myocardial collagen turnover in patients with progressive cardiac conduction disease. Pacing Clin Electrophysiol 2008, 31:1284-1290.

30. Wendling D, Cedoz JP, Racadot E: Serum levels of MMP-3 and cathepsin K in patients with ankylosing spondylitis: effect of TNFalpha antagonist therapy. Joint Bone Spine 2008, 75:559-562.

31. Eldar-Geva T, Spitz IM, Groome NP, Margalioth EJ, Homburg R: Follistatin and activin A serum concentrations in obese and non-obese patients with polycystic ovary syndrome. Hum Reprod 2001, 16:2552-2556.

doi:10.1186/1757-2215-6-32

Cite this article as: van Houten et al: Bone morphogenetic proteins and the polycystic ovary syndrome. Journal of Ovarian Research 2013 6:32.

\section{Submit your next manuscript to BioMed Central and take full advantage of:}

- Convenient online submission

- Thorough peer review

- No space constraints or color figure charges

- Immediate publication on acceptance

- Inclusion in PubMed, CAS, Scopus and Google Scholar

- Research which is freely available for redistribution
C) Biomed Central 